\title{
Cytogenetic Effect of Food Dyes on Cultured Human Cells
}

\author{
Noriho Tanaka and Keida Kitahara \\ Department of Hygiene, Faculty of Medicine, Kagoshima University, Kagoshima
}

\begin{abstract}
Recentry, there has been a rapid increase in the number of chemical compounds, some of which cause a possible genetic hazard as environmental mutagens. A need is growing to establish a suitable screening system for detection of mutagens. Cytogenetic effects of certain food additives such as furylfuramide, cyclamate, saccharin and sodium nitrite have been investigated by several groups of workers, ${ }^{1 \sim 6)}$ but no reports are available on the cytogenetic effect of food dyes which comprise a variety of coal tar dyes, and are widely used in Japan as artificial coloring agents of food, beverages and drugs. We investigated cytogenetic effects of some food dyes, which are authorized by the Japanease Ministry of Health and Welfare, on human leucocytes and fibroblasts. The effects were evaluated on the frequency of chromosome aberrations and the inhibition rate of DNA-synthesis.
\end{abstract}

\section{MATERIALS AND METHODS}

The following 10 food dyes including 6 red, 2 blue and 2 yellow dyes were tested: amaranth, erythrosine, new coccine, phloxine, rose bengale, acid red, brilliant blue FCF, indigocarmine, tartrazine, and sunset yellow FCF.

Chromosome preparation. Human peripheral leucocytes from 10 healthy male donors were cultured according to modifications of procedures first described by Moorhead et al.." Fibroblast cultures (passage 10) were obtained from the skin of a male fetus of 10 weeks gestation.

Eagle's MEM supplemented with $10 \%$ fetal calf serum was used as a culture medium. The blood cultures were incubated for $72 \mathrm{hr}$ at $37^{\circ} \mathrm{C}$ with Colcemid $(0.06-0.10 \mu \mathrm{g} / \mathrm{ml})$ for the final $2 \mathrm{hr}$. As hypotonic treatment $0.075 \mathrm{M} \mathrm{KCl}$ was used, and as fixative methanol: acetic acid $(3: 1)$. Chromosome preparations were made by a air-drying method and Giemsa staining. The test dyes were added $24 \mathrm{hr}$ before harvesting.

Six kinds of red dyes were tested at concentrations of 10 or $50 \mu \mathrm{g} / \mathrm{ml}$, and two each kinds of blue and yellow dyes $1.0,10.0$, and $100.0 \mu \mathrm{g} / \mathrm{m} l$, respectively. These dosages applied as preliminary test were ranging in concentration from $1 \mu \mathrm{g} / \mathrm{m} l$ to $100 \mu \mathrm{g} / \mathrm{m} l$ which are generally used in foods.

Phloxine was further tested at concentrations of $0.05,0.1,0.25,0.5,0.75,1.0,5.0,10.0$, $50.0,100.0$ and $500.0 \mu \mathrm{g} / \mathrm{m} l$. In each experiment 100-120 well-spread metaphase cells were examined and a total of 100-360 cells were scored for a given concentration of dyes. The results were statistically evaluated by the $x^{2}$ test.

DNA-synthesis. Leucocyte cultures containing the same number of cells were prepared after removal of phagocytes by keeping the blood samples in a refrigerator for $1 \mathrm{hr}$ at $4^{\circ} \mathrm{C}$. In addition to dyes, furylfuramide was used as a positive control. ${ }^{3} \mathrm{H}$-thymidine (Specific Activity $14.7 \mathrm{Ci} / \mathrm{m}$ mole) was added to cultures with a final concentration of $0.5 \mu \mathrm{Ci} / \mathrm{m} l 2.5 \mathrm{hr}$ before harvest without Colcemid treatment. After removal of radioactive medium, cells were washed twice with Hanks' solution and a cold 5\% trichloroacetic acid (TCA) by centrifuging at $2500 \mathrm{rpm}$ for $3 \mathrm{~min}$.

The residue was dissolved in $1 \mathrm{ml}$ of $0.1 \mathrm{~N} \mathrm{NaOH}$, and $4.5 \mathrm{ml}$ of $6.5 \%$ TCA was added 
to it. After centrifuging at $2500 \mathrm{rpm}$ for $3 \mathrm{~min}$, the residue was washed with cold methanol and again centrifuged. To the residue dissolved in $0.5 \mathrm{~m} l$ of Soluene-350 (Packard Instrument Company, Inc., USA), was added $0.01 \mathrm{~m} l$ of glacial acetic acid and $10 \mathrm{~m} l$ of toluene scintillator containing $4 \mathrm{~g}$ PPO and $50 \mathrm{mg}$ dimethyl-POPOP per liter. The samples thus prepared were counted in a Beckman Model LS-150 liquid scintillation counter.

\section{RESULTS}

Table 1 shows the frequency of chromosome aberrations after treatment with various dyes under study. Only phloxine produced a significantly higher number of cells with aberrations, while the remaining 9 agents gave no significant increase in the frequency of cells with chromosome aberrations, as compared with controls, within the dosage level here tested. The frequencies of cells with chromosome aberrations in untreated control groups were in the range of $0-5 \%$, in agreement with the reported frequency of spontaneous aberrations. ${ }^{8)}$

As shown in Table 2, the frequency of cells with aberrant chromosomes after phloxine treatment was does dependent. However, at the concentration of $500 \mu \mathrm{g} / \mathrm{m} l$, a complete mitotic inhibition was observed, in parallel with the inhibition of DNA-synthesis as shown in Fig. 3.

Aneuploid cells also increased significantly after phloxine treatment (Table 2). Further noticeable was that embryonic fibroblasts were more sensitive to phloxine as compared with cultured leucocytes (Table 3). Phloxine-induced chromosome aberrations were mostly gaps $(65.7 \%)$ and breaks $(21.5 \%)$ of chromatid type, though acentric fragments $(8.8 \%)$, exchanges $(2.6 \%)$ and deletions $(1.5 \%)$ were less frequently observed (Fig. 1). Dicentrics and inversions were also noted in some instances (Fig. 1). The rate of thymidine incorporation into DNA of cultured leucocytes was dramatically changed by the administration of some of the

Table 1. Chromosome aberrations in $24 \mathrm{hr}$ human leucocyte cultures after treatment with food dyes

\begin{tabular}{|c|c|c|c|c|}
\hline Dyes & $\begin{array}{l}\text { Conc. } \\
(\mu \mathrm{g} / \mathrm{m} l)\end{array}$ & $\begin{array}{l}\text { Donor of } \\
\text { cells* }\end{array}$ & $\begin{array}{l}\text { Total no. of } \\
\text { cells analyzed }\end{array}$ & $\begin{array}{l}\text { Cells with } \\
\text { aberrations (\%) }\end{array}$ \\
\hline Control & 0 & $a, b, c, d$, e. $f$ & 860 & $20(2.3)$ \\
\hline Amaranth (Red, No. 2) & 50 & a. b. c & 300 & $5(1.7)$ \\
\hline Erythrosine (Red, No. 3) & 50 & $\mathrm{a}, \mathrm{b}, \mathrm{c}$ & 300 & $4(1.3)$ \\
\hline New Coccine (Red, No. 102) & 50 & $\mathrm{~b}, \mathrm{c}$ & 200 & $1(0.5)$ \\
\hline Phloxine (Red, No. 104) & 10 & $\mathrm{~d}, \mathrm{e}$ & 200 & $17(8.5)^{* *}$ \\
\hline Rose Bengale (Red, No. 105) & 10 & $\mathrm{~d}, \mathrm{e}$ & 200 & $1(0.5)$ \\
\hline Acid Red (Red, No. 106) & 10 & $\mathrm{~d}, \mathrm{e}$ & 200 & $3(1.5)$ \\
\hline $\begin{array}{l}\text { Brilliant Blue FCF } \\
\text { (Blue, No. 1) }\end{array}$ & $\begin{array}{r}1 \\
10 \\
100\end{array}$ & $\begin{array}{l}\text { d, e, f } \\
\text { d, e,f } \\
\text { d, e, f }\end{array}$ & $\begin{array}{l}360 \\
360 \\
360\end{array}$ & $\begin{array}{l}13(3.6) \\
12(3.3) \\
22(6.1)\end{array}$ \\
\hline $\begin{array}{l}\text { Indigocarmine } \\
\text { (Blue, No. 2) }\end{array}$ & $\begin{array}{r}1 \\
10 \\
100\end{array}$ & $\begin{array}{l}\mathrm{d}, \mathrm{e}, \mathrm{f} \\
\mathrm{d}, \mathrm{e}, \mathrm{f} \\
\mathrm{d}, \mathrm{e}, \mathrm{f}\end{array}$ & $\begin{array}{l}360 \\
360 \\
360\end{array}$ & $\begin{array}{l}16(4.4) \\
10 .(2.8) \\
12(3.3)\end{array}$ \\
\hline $\begin{array}{l}\text { Tartrazine } \\
\text { (Yellow, No. 4) }\end{array}$ & $\begin{array}{r}1 \\
10 \\
100\end{array}$ & $\begin{array}{l}d, e, f \\
d, e, f \\
d, e, f\end{array}$ & $\begin{array}{l}360 \\
360 \\
360\end{array}$ & $\begin{array}{ll}15 & (4.2) \\
18 & (5.0) \\
15 & (4.2)\end{array}$ \\
\hline $\begin{array}{l}\text { Sunset Yellow FCF } \\
\text { (Yellow, No. 5) }\end{array}$ & $\begin{array}{r}1 \\
10 \\
100\end{array}$ & $\begin{array}{l}\text { d, e, f } \\
\text { d, e,f } \\
\text { d, e, f }\end{array}$ & $\begin{array}{l}360 \\
360 \\
360\end{array}$ & $\begin{array}{l}15(4.2) \\
11(3.1) \\
15(4.2)\end{array}$ \\
\hline
\end{tabular}

* Blood samples were provided by 6 healthy male donors.

** $\mathrm{P}<0.001$ in comparison with the control groups in each experiment. 
Table 2. Chromosome aberrations in $24 \mathrm{hr}$ human leucocyte cultures after treatment with various concentrations of phloxine (Red, No. 104)

\begin{tabular}{|c|c|c|c|c|c|c|c|}
\hline \multirow[b]{2}{*}{$\begin{array}{l}\text { Conc. } \\
(\mu \mathrm{g} / \mathrm{m} l)\end{array}$} & \multirow[b]{2}{*}{$\begin{array}{l}\text { Donor of } \\
\text { cells***** }\end{array}$} & \multirow{2}{*}{$\begin{array}{l}\text { Total no. } \\
\text { of cells } \\
\text { analyzed }\end{array}$} & \multirow{2}{*}{$\begin{array}{l}\text { Cells with } \\
\text { aberrations } \\
(\%)\end{array}$} & \multicolumn{3}{|c|}{ Types and numbers of aberrations } & \multirow{2}{*}{$\begin{array}{l}\text { Total no. of } \\
\text { aneuploid } \\
\text { cells }(\%)\end{array}$} \\
\hline & & & & $\begin{array}{l}\text { chromatid } \\
\text { gaps and } \\
\text { breaks }\end{array}$ & $\begin{array}{l}\text { isochromatid } \\
\text { gaps and } \\
\text { breaks }\end{array}$ & others & \\
\hline Control & $\mathrm{g}, \mathrm{h}, \mathrm{i}, \mathrm{j}$ & 407 & $11(2.7)$ & 10 & 1 & 0 & $4(1.0)$ \\
\hline 0.05 & $\mathrm{j}$ & 100 & $4(4.0)$ & 3 & 1 & 0 & $1(1.0)$ \\
\hline 0.10 & $\mathrm{~g}, \mathrm{~h}, \mathrm{i}$ & 314 & $8(2.6)$ & 6 & 1 & 1 & $11(3.5)$ \\
\hline 0.25 & $\mathrm{j}$ & 100 & $5(5.0)$ & 3 & 2 & 0 & $2(2.0)$ \\
\hline 0.50 & $\mathrm{~g}, \mathrm{~h}, \mathrm{i}$ & 326 & $14(4.3)$ & 8 & 4 & 2 & $10(3.1)$ \\
\hline 0.75 & $\mathrm{j}$ & 100 & $7(7.0)$ & 5 & 0 & 2 & $3(3.0)$ \\
\hline 1.00 & $\mathrm{~g}, \mathrm{~h}, \mathrm{i}$ & 327 & $* * 23(7.0)$ & 16 & 5 & 2 & $14(4.3) *$ \\
\hline 5.00 & $\mathrm{~g}, \mathrm{~h}, \mathrm{i}$ & 326 & $* * * 37(11.4)$ & 24 & 8 & 5 & $15(4.6) *$ \\
\hline 10.00 & $\mathrm{~g}, \mathrm{~h}, \mathrm{i}$ & 339 & $* * * 30(8.9)$ & 19 & 4 & 7 & $24(7.1)^{* * *}$ \\
\hline 50.00 & $\mathrm{~g}, \mathrm{~h}, \mathrm{i}$ & 329 & ***37 (11.2) & 26 & 6 & 5 & $14(4.3)^{*}$ \\
\hline 100.00 & $\mathrm{~g}, \mathrm{~h}, \mathrm{i}$ & 326 & $* 22(6.7)$ & 15 & 4 & 3 & $19(5.8)^{* *}$ \\
\hline 500.00 & $\mathrm{~g}, \mathrm{~h}, \mathrm{i}$ & No mitosis & - & - & - & - & - \\
\hline
\end{tabular}

$* \mathrm{P}<0.05 * * \mathrm{P}<0.01 * * * \mathrm{P}<0.001$ in comparison with the control groups in each experiment. **** Blood samples were provided by 4 healthy male donors.

Table 3. Chromosome aberrations in $24 \mathrm{hr}$ human fibroblast cell cultures after treatment with different concentrations of phloxine (Red, No. 104)

\begin{tabular}{c|c|c|c}
\hline $\begin{array}{l}\text { Conc. } \\
(\mu \mathrm{g} / \mathrm{m} l)\end{array}$ & $\begin{array}{c}\text { Total no. of cells } \\
\text { analyzed }\end{array}$ & $\begin{array}{l}\text { Cells with } \\
\text { aberrations }\end{array}$ & $\begin{array}{c}\text { Percentage of cells } \\
\text { with aberrations }\end{array}$ \\
\hline Control & 215 & 6 & 2.8 \\
1.0 & 236 & 22 & $9.3^{*}$ \\
10.0 & 234 & 29 & $12.4^{* *}$ \\
100.0 & 251 & 42 & $16.7^{* *}$ \\
\hline
\end{tabular}

$* \mathrm{P}<0.05 * * \mathrm{P}<0.001$ in comparison with the control.

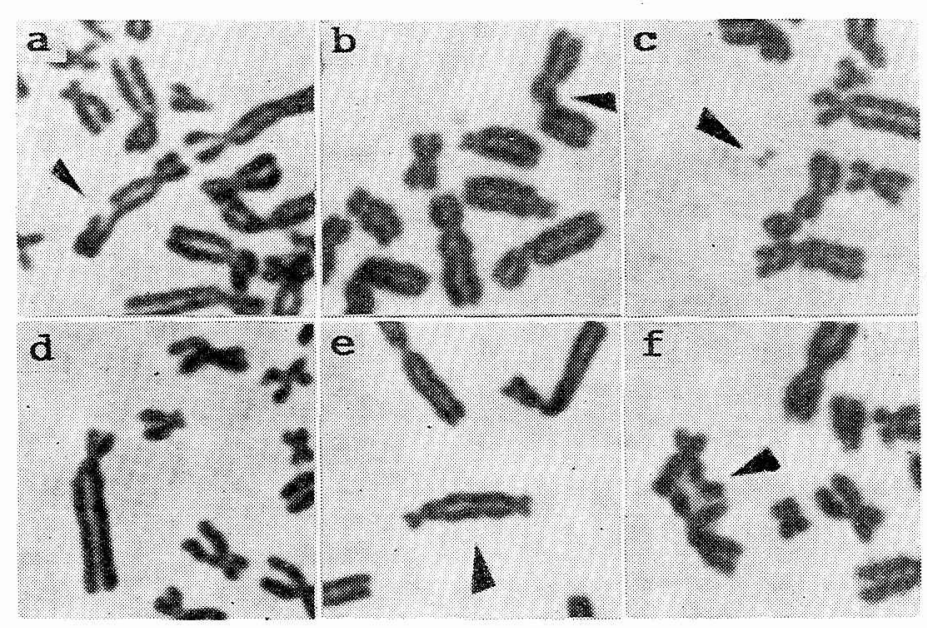

Fig. 1. Phloxine-induced chromosome aberrations (arrowed)
a. chromatid break,
b. isòchromatid break,
c. fragment,
d. pericentric inversion,
e. dicentric,
f. chromatid exchanges. 


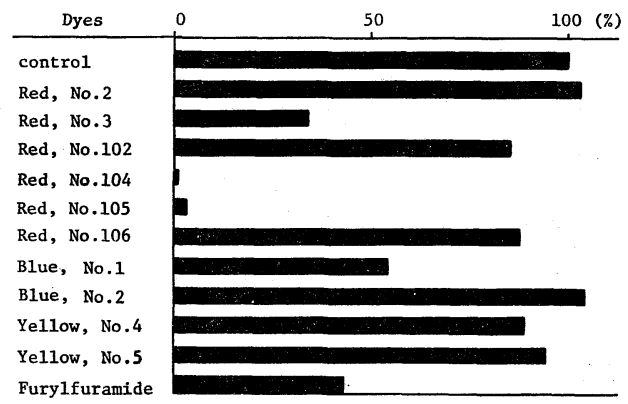

Fig. 2. The rate of DNA-synthesis in leucocyte cultures after treatments $(500 \mu \mathrm{g}$ / $\mathrm{m} l$ in each) 10 food dyes and 1 food preservative.

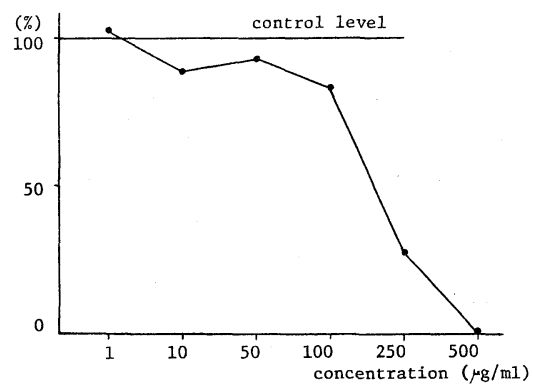

Fig. 3. Comparison of DNA-synthesis in leucocyte cultures treated with different concentrations of phloxine.

food dyes (Fig. 2). The inhibition rates of DNA-synthesis were 99.6\% for phloxine, 96.8\% for rose bengale, and $73.2 \%$ for erythrosine, respectively. These dyes showed an extremely high cytotoxicity as compared with furylfuramide for which the inhibition rate was $57 \%$.

The remaining 7 agents showed moderate or a lesser extent of inhibitions, although almost no inhibition was observed in amaranth and indigocarmine. The inhibition of DNAsynthesis was apparently dose dependent as revealed by an experiment with different concentrations of phloxine (Fig. 3).

\section{DISCUSSION}

In view of the close relationship of food dyes to mutagenic, carcinogenic and probably teratogenic potencials, taking the safety measures regarding food dyes is a matter of great urgency, since various kinds of food dyes are currently in use. The present experiments indicate that three xanthin-dyes: erythrosine, phloxine, and rose bengale, having a similar chemical structure, exert a drastic inhibitory effect of DNA-synthesis on human cells, and that phloxine induces chromosome aberrations in cultured lymphocytes and fibroblasts, although its frequency was lower than that of furylfuramide reported previously. ${ }^{1)}$ It should be mentioned that the inhibition rate of DNA-synthesis and the frequency of chromosome aberration after phloxine treatments were dose dependent and that embryonic fibroblasts were mores sensitive than cultured lymphocytes in terms of the yield of chromosome aberrations. It should also be mentioned that the mutagenic activity of phloxine has been revealed by Kada et al. ${ }^{9)}$ using the rec-assay system in bacteria. Sasaki and $\mathrm{Abe}^{10)}$ studied cytogenetic effects of amaranth and erythrosine on mouse bone marrow cells and found that amaranth induced a severe mitotic inhibition and possibly chromosome aberrations, while erythrosine exerted no appreciable effects. Our results were rather contradictory in that amaranth showed no effects and erythrosine produced a higher mitotic disturbance. This is probably due to the different experimental conditions, such as in vitro and in rivo, species, cell types, and dossages applied. Several food dyes are generally known to produce some metabolites by the action of the liver and kidney microsomal enzymes and the reductive action of the gut microflora. Consequently these metabolites and degradation products which are activated in vivo should be tested. Further improvement and devices of the screening system are thus requested for the detection of induced chromosome aberrations by environmental potential mutagens. 


\title{
SUMMARY
}

Cytogenetic effects of 10 kinds of food dyes were studied on human leucocytes and fibroblasts in vitro. Among the dyes tested phloxine induced structural chromosome aberrations involving mostly gaps and breaks of chromatid type, whereas the other dyes did not induce aberrations within the limit of the present experiments. Three xanthin-dyes, erythrosine, phloxine, and rose bengale, were found to be strong inhibitors of DNA-synthesis, showing a significantly reduced thymidine incorporation, while the remaining 7 agents including 5 azodyes showed moderate or no inhibitions.

\section{ACKNOWLEDGEMENT}

The authors are grateful to Professor M. Sasaki, Chromosome Research Unit, Faculty of Science, Hokkaido University, for valuable suggestions during the preparation of this manuscript, and to Dr. T. Furusho, Department of Hygiene, Faculty of Medicine, Kagoshima University, for many helpful advices during this work.

\section{REFERENCES}

1) Tonomura, A. and Sasaki, M.: Chromosome aberrations and DNA repair synthesis in cultured human cells exposed to nitrofurans, Japan J. Genet., 48, 291-294 (1973).

2) Wild, D.: Mutagenicity of the food additives AF-2, a nitrofuran, in Escherichia coli and Chinease hamster cells in culture, Mutation Res., 31, 197-199 (1975).

3) Brewen, J. G., Pearson, F. G., Jones, P., Luippold, H. E.: Cytogenetic effects of cyclohexylamine and N-OH-cyclohexylamine on human leucocytes and Chinease hamster bone marrow, Nature New Biology, 230, 15-16 (1971).

4) Stoltz, D. R., Khera, K. S., Bendall, R., Gunner, S. W.: Cytogenetic studies with cyclamate and related compounds, Science, 167, 1501-1502 (1970).

5) Stone, D., Lamson, E., Chang, Y. S., Pickering, K. W.: Cytogenetic effects of cyclamates on human cells in vitro, Science, 164, 568-569 (1969).

6) Couch, D. B. and Friedman, M. A.: Interactive mutagenicity of sodium nitrite, dimethylamine, methylurea and ethylurea, Mutation Res., 31, 109-114 (1975).

7) Moorhead, P. S., Nowell, P. C., Mellman, W. J., Battips, D. M., and Hungorford, D. A.: Chromosome preparations of leukocytes cultured from human peripheral blood, Exptl. cell Res., 20, 613-616 (1960).

8) Ford, E. H. R.: In "Human chromosome" (Editor: Ford, E. H. R.), 279-284, Academic press, New York and London (1973).

9) Kada. T., Sakaie, Y. and Tuchikawa, K.: In vitro and host-mediated "rec-assay" procedures for screening chemical mutagens, and phloxine, a mutagenic red dye detected, Mutation Res., 16 165174 (1972).

10) Sasaki, M. and Abe, S.: A preliminary note on acute cytogenetic effects of oncogenic and nononcogenic chemicals upon mouse bone marrow cells, Chromosome Informations Service, 17, 31-32 (1974).

\section{食用色素の人培養細胞における細胞遺伝学的影響}

\author{
鹿児島大学・医学部衛生学教室 \\ 田 中憲 穂・北原 経 太
}

合成着色料の人培養細胞における細胞遺伝学的影響を正常健康人リンパ球及び胎児細胞を用いて検討した。字 験に用いた10種類の色素の中で phloxine は染色体異常を誘起し，その異常の大部分は gaps や breaks からなる 染色分体型の異常であった。また phloxine の添加濃度に応じ染色体異常が増加する傾向がみられた。しかしな がら他の 9 種頑の色素は本実験条件下ではコントロールとの間に有意差が認められなかった。DNA 合成への影 響についてはキサンチン色素に属する種類の色素 erythrosine phloxine, rose bengale はDNA 合成に強い阻害 を示した。一方アゾ色素 5 種類含む他の 7 種類の色素ではその阻害は弱いかまたは全く認められなかった。 